УДК 903.2

DOI: $10.17223 / 19988613 / 42 / 18$

\title{
И.В. Ковтун
}

\section{КЛИНКОВОЕ ОРУЖИЕ СЕЙМИНСКО-ТУРБИНСКИХ ГРУППИРОВОК}

\begin{abstract}
Статья посвящена оригинальным разновидностям кинжалов сейминско-турбинской эпохи, различающихся морфологически, а также по иконографическим и стилистическим особенностям их зооморфных наверший. Рассматриваются характерные особенности статусного клинкового оружия сейминско-турбинских группировок. Особое место отведено кинжалам сопкинскокаракольского типа. Распространение данных изделий соотносится с доминантным меридиональным направлением межкультурных взаимодействий на ранних этапах сейминско-турбинской эпохи. Высказана идея о необходимости удревнения хронологических рамок Центральноазиатской металлургической провинции.

Ключевые слова: кинжалы; копья; морфология; сейминско-турбинский феномен; хронология.
\end{abstract}

В 2014-2015 гг. в научный оборот была введена серия дат по ${ }^{14} \mathrm{C}$ [1. С. 464-466; 2. С. 105; 3. Р. 598, Tab. 1; P. 599, Fig. 3, 2], позволяющих переосмыслить изложенные ранее представления [4. С. 322-325] о генерации и хронологии оригинальных кинжалов из могильника Сопка II (Сопка-2/4Б, В). Культурнохронологической переоценке подлежит и типологически аналогичная сопкинским изделиям серия алтайских и центральноазиатских кинжалов, в том числе и с фигурными навершиями.

Появление такого особого типа кинжалов у кротовского населения Барабы соответствует исторической логике аналогичного процесса у всех сейминскотурбинских сообществ. Сочетание технологии литой «слепой» втулки и «рёбер жёсткости», олицетворяющих сейминско-турбинскую металлургическую традицию, воплощено в триаде бронзовых изделий с условным грифом «Три “К”»: кельты, копья и клинки. Но не кельты и копья, а именно клинковое оружие главным образом выступает символом и индикатором этнокультурного своеобразия сейминско-турбинских группировок.

Каждой культурной группе или мультикультурному сообществу металлургов, отнесённых к сейминскотурбинскому феномену, наряду с утилитарными формами, присущи и оригинальные типы клинкового оружия: статусных ножей и / или кинжалов, чаще со скульптурным навершием. Такие клинки собственно сейминско-турбинского облика представлены выгнутообушковыми ножами с двух- или трёхфигурными композициями в навершии либо без них (Сейма, Турбино II, Ростовка, p. Джумба, из-под г. Омска, Увэр-Хангайский аймак, Центральная Монголия) (рис. 1, 1-6). Смысловое значение каждой скульптурной группы уникально, но общим знаменателем данных изображений представляется идея жертвоприношения коня, барана, лося и, возможно, даже человека.

Галичский локус символизируют кинжалы с фигурно-парциальными рукоятями-навершиями, конструктивно напоминающие протососново-мазинскую форму (Галич, Сейма, Пермь) (рис. 2, 7-9). Семантические планы скульптурно-изобразительных композиций этих изделий соотносятся с моделью мироздания и архаичными вариациями змее/драконоборческого мифа.
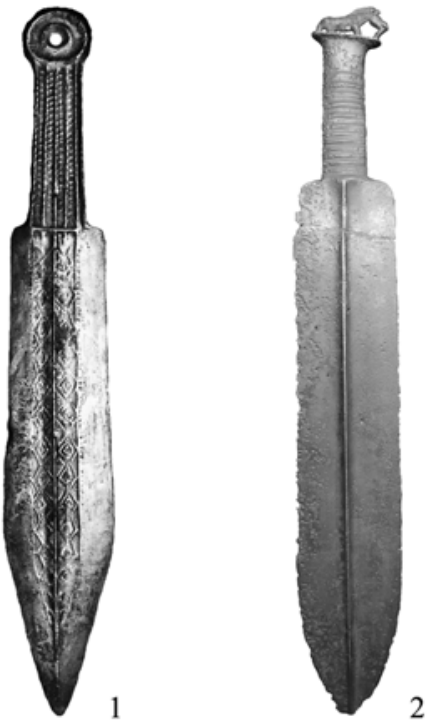

Рис. 1. Кинжалы: 1 - из-под г. Омска [5. С. 67. Рис. 17]; $2-$ г. Шемонаиха [4. Фото 161, 2]

Елунинские прямолезвийные ножи с парциальными навершиями (Елунино I, Усть-Мута) (рис. 2, 10, 11) также не имеют параллелей за пределами Алтая. Наиболее близкие мифологические параллели стилизованных конских скульптурок обоих ножей, на мой взгляд, связаны с образами ведийского коня Эташи и коня-змееборца.

Совершенно особая форма отличает кинжалы из разрушенного могильника под г. Омском (Ростовка ?) и из г. Шемонаихи [4. С. 325; 5. С. 68], один с навершием и оба с семантически значимой орнаментацией клинка и рукояти соответственно (см. рис. 1). Идейное значение орнаментальной композиции омского клинка и скульптурное навершие шемонаихского экземпляра содержательно дополняют друг друга. Полагаю, они символизируют конское жертвоприношение, близкое ашвамедхе, приносимое во время полнолуния. 

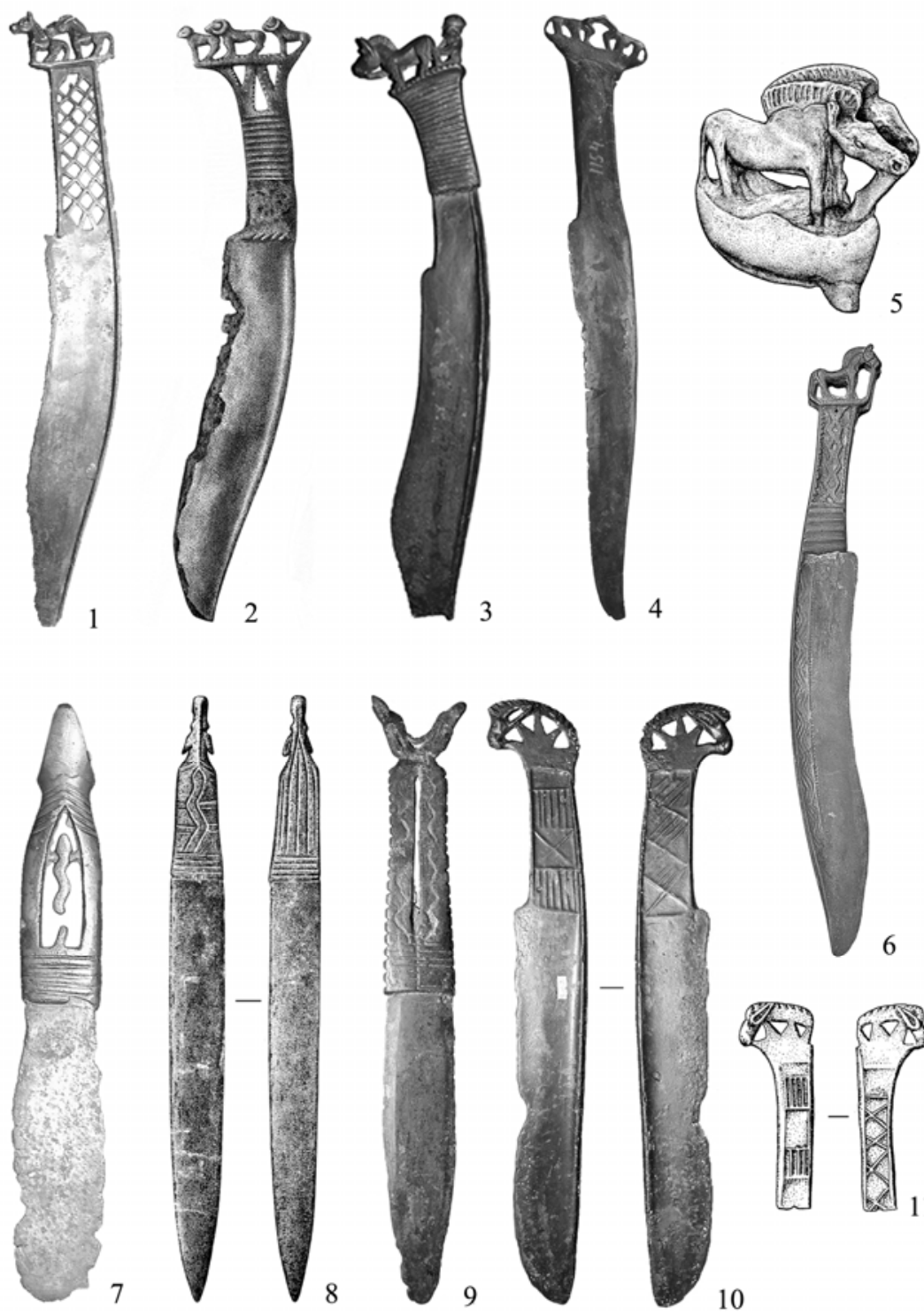

Рис. 2. 1 - Сейма [4. Фото 32]; 2 - Турбино II [10. Рис. 113]; 3 - Ростовка [4. Фото 47]; 4 - p. Джумба [4. Фото 151];

5 - Увэр-Хангайский аймак (Центральная Монголия) [11. С. 143, рис. 2, 5]; 6 - из-под г. Омска [4. Фото 67];

7 - Галичский клад [4. Фото 6, 1, 2]; 8 - Сейма [12. С. 116, рис. 50]; 9 - г. Пермь [4. Фото 18]; 10 - Елунино I [4. Фото 1]; 11 - Усть-Мута [13. С. 166]

Наконец, особенной морфологией и территориальной локализацией [6. С. 98, рис. 1] выделяются сопкинско-каракольские кинжалы с двутавровыми или подовальными рукоятями (рис. 3). Их неординарный статус удостоверяется экземплярами с монофигурными навершиями и связью с образами детей (погребённых, богов, героев и т.п.) [4. С. 331336; 7. С. 277-284]. В этой сводке кинжалы сопкинско-каракольского типа адекватны парадигме, присущей всей сейминско-турбинской металлургической традиции и сочетающей унификацию номенклатурного ряда с оригинальностью и даже уникальностью его отдельных образцов.

Для сопкинско-каракольских изделий характерно широкое распространение в меридиональном направлении, что отличается от локализации собственно сейминско-турбинских клинков выгнутообушковых форм.
Вероятно, это указывает на доминанту транскультурных связей, присущих времени генерации и/или бытования кинжалов подобного типа. Полагаю, период распространения и ареал данных изделий соотносимы с территориально-хронологическим континуумом Центральноазиатской (Восточноазиатской) металлургической провинции, подлежащей удревнению с карасукского времени до сейминско-турбинской эпохи [4. С. 23, 31 и др.].

Сейминско-турбинская атрибуция кинжалов сопкинско-каракольского типа придаёт данной идее существенный аргумент и новые предметные формы. Это соотносится и с концептуальным выводом о вхождении кротовской культуры в северо-восточную оконечность ареала весьма специфичной традиции металлургического производства культур ранней - развитой бронзы Евразии [8. С. 117]. 


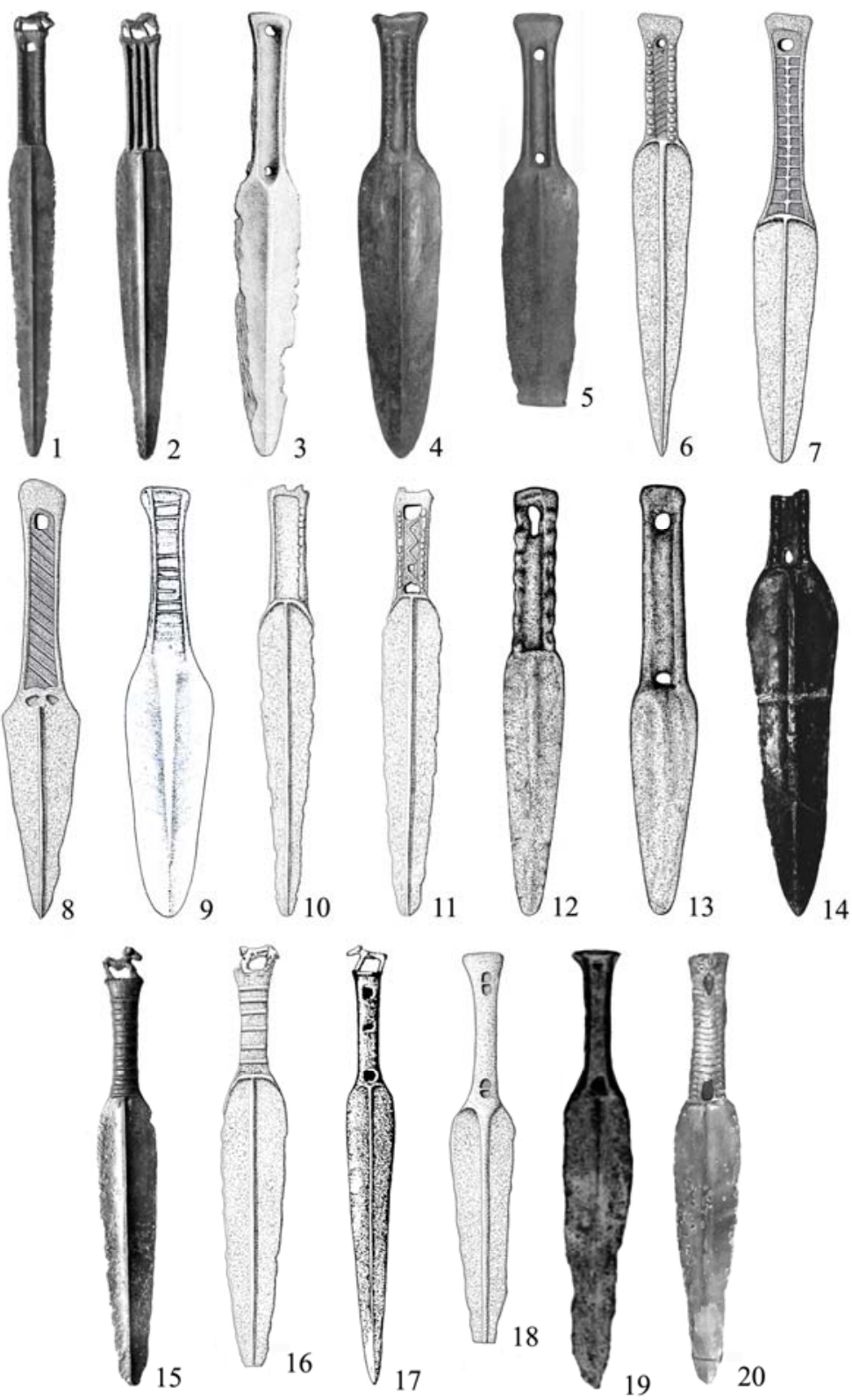

Рис. 3. Кинжалы: 1 - с. Чарышское [4. Фото 162, 1]; 2 - Второй Каракольский клад [4. Табл. 4, 1]; 3-5 - Сопка-2/4Б, В [9. С. 5-6, рис. 1-3 (фото И.В. Ковтуна)]; 6- сов. «Урожайный» [4. Табл. 111, 3];

7 - б. Енисейская губ. [4. Табл. 111, 7]; 8- Восточный Казахстан [4. Табл. 111, 8]; 9- с. Павлодарское [14. С. 16, рис. 4, 1; цв. вкл. IX, 5]; 10 - Второй Каракольский клад [4. Табл. 111, 10]; 11 - Второй Каракольский клад [4. Табл. 111, 11]; 12, 13 - уезд Тяньшуй провинции Ганьсу (КНР) [11. С. 143, рис. 2, 2, 3];

14 - окрестности с. Конево, Краснозёрский р-н, Новосибирской обл. [15. С. 67]; 15, 16 - Второй Каракольский клад [4. Табл. 111, 13, 14]; 17 - Курчум [4. Табл. 111, 15]; 18 - Семипалатинск [4. Табл. 111, 16]; 19 - долина р. Или, пригород Цяолакерек [16. С. 276, рис. 161В, 4]; 20 - Змеиногорск-IV [14. Цв. вкл. IV, 8]

Морфология клинков сопкинско-каракольских кинжалов сопоставима с пропорционально-параметрическими характеристиками перьев сейминско-турбинских копий [9. С. 9]. Это особенно заметно по ширине клинка одного из сопкинских кинжалов [6. С. 98], возможно, самого архаичного экземпляра в серии [4. С. 323]. Поэтому в качестве составной части сейминско- турбинского оружейного комплекса [6. С. 104-105] сопкинские находки могут быть древнейшими среди известных сейчас кинжалов подобного типа. Отмеченное соответствие означает собственно сейминскотурбинские истоки данного типа клинкового оружия, генерация которого, вероятно, восходит к «общей матрице» с сейминско-турбинскими копьями.

\section{ЛИТЕРАТУРА}

1. Марченко Ж.В., Молодин В.И., Гришин А.Е., Орлова Л.А. Погребальные комплексы с предметами сейминско-турбинского и кенкольского типов в Барабинской лесостепи (Западная Сибирь) и их радиоуглеродная хронология // Труды IV (XX) Bсероссийского археологического съезда в Казани. Казань, 2014. С. 463-468. 
2. Молодин В.И. Феномен бронзовых кинжалов из погребальных комплексов кротовской культуры (хронология, территория распространения, истоки) // Вестник Кемеровского государственного университета. 2015. № 2 (62). Т. 6. С. 97-107.

3. Marchenko Z.V., Orlova L.A., Panov V.S., Zubova A.V., Molodin V.I., Pozdnyakova O.A., Grishin A.E., Uslamin E.A. Paleodiet, radiocarbon chronology, and the possibility of fresh-water reservoir effect for Preobrazhenka 6 burial ground, Western Siberia: preliminary results // Radiocarbon. 2015. Vol. 57, № 4. P. 595-610.

4. Ковтун И.В. Предыстория индоарийской мифологии. Кемерово, 2013. 702 с.

5. Молодин В.И., Нескоров А.В. Коллекция сейминско-турбинских бронз из Прииртышья (трагедия уникального памятника - последствия бугровщичества XXI века) // Археология, этнография и антропология Евразии. 2010. № 3 (43). С. $58-71$.

6. Молодин В.И. Феномен бронзовых кинжалов из погребальных комплексов кротовской культуры (хронология, территория распространения, истоки) // Вестник Кемеровского государственного университета. 2015. № 2 (62). Т. 6. С. 97-107.

7. Ковтун И.В. Изображение младенца с кинжалом (постсейминский тип кинжалов в контактной зоне Евразийской и Центральноазиатской металлургических провинций) // Проблемы археологии, этнографии, антропологии Сибири и сопредельных территорий. Новосибирск, 2004. T. Х, ч. I. С. 277-285.

8. Молодин В.И., Дураков И.А., Мыльникова Л.Н., Нестерова М.С. Производственный комплекс кротовской культуры на поселении Венгерово-2 (Барабинская лесостепь) // Вестник Новосибирского государственного университета. Серия: История, филология. 2012. Т. 11, вып. 5: Археология и этнография. С. 104-119.

9. Молодин В.И. Новый вид бронзовых кинжалов в погребениях кротовской культуры // Военное дело населения юга Сибири и Дальнего Востока. Новосибирск, 1993. С. 4-16.

10. Бадер О.Н. Древнейшие металлурги Приуралья. М., 1964. 176 с.

11. Ковалёв А.А. Новые данные о связях культур Западной Сибири, Монголии и Китая в первой половине II тыс. до н.э. // Современные решения актуальных проблем евразийской археологии. Барнаул, 2013. С. 140-146.

12. Бадер О.Н. Бассейн Оки в эпоху бронзы. М., 1970. 176 с.

13. Киреев С.М., Кудрявцев П.И. Новые находки эпохи бронзы из Горного Алтая // Хронология и культурная принадлежность памятников каменного и бронзового веков Южной Сибири. Барнаул, 1988. С. 164-168.

14. Грушин С.П., Мерц В.К., Папин Д.В., Пересветов Г.Ю. Материалы эпохи бронзы из Павлодарского Прииртышья // Алтай в системе металлургических провинций бронзового века. Барнаул, 2006. С. 4-17.

15. Из музейных собраний Новосибирской области. Каталог / сост. Н.В. Ермакова, М.А. Овчарова / под ред. А.В. Шаповалова. Новосибирск, 2009. $158 \mathrm{c}$.

16. Новоженов В.А. Чудо коммуникации и древнейший колёсный транспорт Евразии. М., 2012. 500 с.

Kovtun Igor V. Institute of Human Ecology of the FSBSI The Federal research center of coal and coal chemistry of Siberian Branch of the RAS (Kemerovo, Russia). E-mail: ivkovtun@mail.ru

\section{BLADED WEAPON OF SEYMINO-TURBINO GROUPS.}

Keywords: daggers; spears; morphology; Seymino-Turbino phenomena; chronology.

The article deals with the original types of daggers of Seymino-Turbino time, which differ in morphology, as well as in iconographic and stylistic peculiarities of their zoomorphic knobs. Some characteristics of status blade weapon of Seymino-Turbino groups are analyzed. A special attention is given to Sopkino-Karakol type of daggers. The spread of such objects is associated with the dominant meridional direction of inter-cultural interactions of early stages of Seymino-Turbino time. Appearance of such special dagger type in Krotovo population of Baraba corresponds to the historical logic of the similar process in all Seymino-Turbino communities. It is the blade weapon which is the symbol and indicator of ethno-cultural specifics of Seymino-Turbino groups. Such blades are knives with or without ornamental compositions on the knobs (Seyma, Turbino II, Rostovka, r. Dzhumba, near Omsk, Övörkhangai Province, Central Mongolia). Daggers with body part knobs symbolize Galich location (Galich, Seyma, Perm). Elunino straight blade knives (Elunino I, Ust-Muta) do not have parallels outside Altai. Daggers from the ruined burial mound of Omsk area and Shemonaikha have a special form. Finally, Sopkino-Karakol daggers have a special morphology and territorial location. Their special status is proven by some of them with ornamented knobs and association with child images (buried people, gods, heroes etc). The period of spread and area of these objects are correlated with Central Asia (Eastern Asia) metallurgical province, which dates have to be changed form Karasuk period to Seymino-Turbino time. The morphology of Sopkino-Karakol dagger blades can be compared with proportions and parameters of Seymino-Turbino spear points. The most noticeable characteristic is the width of the blade of a Sopkino dagger, perhaps the most archaic one within the range. Therefore, as a component of Seimino-Turbino weapon complex, Sopkino findings can be the most ancient ones among known daggers of this type. This noticed correspondence indicates to Seymino-Turbino origins of the blade weapon of this type, which apparently has the "common matrix" with Seymino-Turbino spears.

\section{REFERENCES}

1. Marchenko, Zh.V., Molodin, V.I., Grishin, A.E. \& Orlova, L.A. (2014) Pogrebal'nye kompleksy s predmetami seyminsko-turbinskogo i kenkol'skogo tipov v Barabinskoy lesostepi (Zapadnaya Sibir') i ikh radiouglerodnaya khronologiya [Funerary complexes with objects of the Seima-Turbino and Kenkolsk types in Baraba forest-steppe (Western Siberia) and their radiocarbon chronology]. In: Sitdikov, A.G., Makarov, N.A. \& Derevyanko, A.P. (eds) Trudy IV (XX) Vserossiyskogo arkheologicheskogo s"ezda v Kazani [Proceedings of the Fourth All-Russian Archeological Congress in Kazan]. Kazan: Otechestvo. pp. 463-468.

2. Molodin, V.I. (2015) The Neolithic of forest-steppe Transurals and Irtysh area: Latest research and periodization. Vestnik Kemerovskogo gosudarstvennogo universiteta - Bulletin of Kemerovo State University. 6(2). pp. 97-107. (In Russian). DOI: 10.21603/2078-8975-2015-2-108-113

3. Marchenko, Z.V., Orlova, L.A., Panov, V.S., Zubova, A.V., Molodin, V.I., Pozdnyakova, O.A., Grishin, A.E. \& Uslamin, E.A. (2015) Paleodiet, radiocarbon chronology, and the possibility of fresh-water reservoir effect for Preobrazhenka 6 burial ground, Western Siberia: preliminary results. $R a-$ diocarbon. 57(4). pp. 595-610. DOI: 10.2458/azu_rc.57.18435

4. Kovtun, I.V. (2013) Predystoriya indoariyskoy mifologii [Prehistory of Indo-Aryan mythology]. Kemerovo: Human Ecology Institute of Russian Academy of Sciences.

5. Molodin, V.I. \& Neskorov, A.V. (2010) Kollektsiya seyminsko-turbinskikh bronz iz Priirtysh'ya (tragediya unikal'nogo pamyatnika - posledstviya bugrovshchichestva XXI veka) [The collection of Seima-Turbino bronzes of the Irtysh Area (The tragedy of the unique monument - the consequences of illegal excavations in the 21st century)]. Arkheologiya, etnografiya i antropologiya Evrazii-Archaeology, Ethnology \& Anthropology of Eurasia. 3(43). pp. 58-71.

6. Molodin, V.I. (2015) The phenomenon of bronze daggers from burial complexes of the Krotovo culture (chronology, area of distribution, beginnings). Vestnik Kemerovskogo gosudarstvennogo universiteta - Bulletin of Kemerovo State University. 6(2). pp. 97-107. (In Russian). DOI: 10.21603/20788975-2015-2-97-107 
7. Kovtun, I.V. (2004) Izobrazhenie mladentsa s kinzhalom (postseyminskiy tip kinzhalov v kontaktnoy zone Evraziyskoy i Tsentral'noaziatskoy metallurgicheskikh provintsiy) [The image of a baby with a dagger (the Postseyminsk type of daggers in the contact zone of the Eurasian and Central Asian metallurgical provinces)]. In: Derevyanko, A.P. \& Molodin, V.I. (eds) Problemy arkheologii, etnografii, antropologii Sibiri i sopredel'nykh territoriy [Problems of archeology, ethnography, anthropology of Siberia and adjacent territories]. Vol. 10(1). Novosibirsk: Institute of Archeology and Ethnography SB RAS. pp. 277-285.

8. Molodin, V.I., Durakov, I.A., Mylnikova, L.N. \& Nesterova, M.S. (2012) Proizvodstvennyy kompleks krotovskoy kul'tury na poselenii Vengerovo-2 (Barabinskaya lesostep') [The industrial complex of Krotovo culture at Vengerovo-2 (the Baraba forest-steppe)]. Vestnik Novosibirskogo gosudarstvennogo universiteta. Seriya: Istoriya, filologiya - Vestnik of Novosibirsk State University. History and Pholology. 11(5). pp. 104-119.

9. Molodin, V.I. (1993) Novyy vid bronzovykh kinzhalov v pogrebeniyakh krotovskoy kul'tury [A new type of bronze daggers in the graves of the Krotovo Culture]. In: Medvedev, V.E. \& Khudyakov, Yu.S. (eds) Voennoe delo naseleniya yuga Sibiri i Dal'nego Vostoka [The military art of the peoples in Southern Siberia and the Far East]. Novosibirsk: Nauka. pp. 4-16.

10. Bader, O.N. (1964) Drevneyshie metallurgi Priural'ya [The ancient metallurgists of the Urals]. Moscow: Nauka.

11. Kovalev, A.A. (2013) Novye dannye o svyazyakh kul'tur Zapadnoy Sibiri, Mongolii i Kitaya v pervoy polovine II tys. do n.e. [New data on the links bwtween Western Siberian, Mongolian and Chinese cultures in the early 2nd millennium BC.]. In: Tishkin, A.A. (ed.) Sovremennye resheniya aktual'nykh problem evraziyskoy arkheologii [Modern solutions for urgent problems of Eurasian archeology]. Barnaul: Altai State University. pp. 140146.

12. Bader, O.N. (1970) Basseyn Oki v epokhu bronzy [The Oka Basin in the Bronze Age]. Moscow: Nauka.

13. Kireev, S.M. \& Kudryavtsev, P.I. (1988) Novye nakhodki epokhi bronzy iz Gornogo Altaya [New finds of the Bronze Age in Gorny Altai]. In: Deravyanko, A.P. (ed.) Khronologiya i kul'turnaya prinadlezhnost' pamyatnikov kamennogo i bronzovogo vekov Yuzhnoy Sibiri [Chronology and cultural belonging of the Stone and Bronze Age monuments in Southern Siberia]. Barnaul: Altai State University. pp. $164-168$.

14. Grushin, S.P., Merts, V.K., Papin, D.V. \& Peresvetov, G.Yu. (2006) Materialy epokhi bronzy iz Pavlodarskogo Priirtysh'ya [Materials of the Bronze Age from Pavlodar Region]. In: Grushin, S.P. et al. Altay v sisteme metallurgicheskikh provintsiy bronzovogo veka [Altai in the system of metallurgical provinces of the Bronze Age]. Barnaul: Altai State University. pp. 4-17.

15. Shapovalov, A.V. (ed.) (2009) Iz muzeynykh sobraniy Novosibirskoy oblasti [From the museum collections of Novosibirsk Region]. Novosibirsk: Siberian Museum Agency, Taler-Press.

16. Novozhenov, V.A. (2012) Chudo kommunikatsii i drevneyshiy kolesnyy transport Evrazii [The wonders of communication and the ancient wheel transport in Eurasia]. Moscow: TAUS. 